\title{
Aydın Ekolojisinde Badem Çeșitlerinin Biyokimyasal Özellikleri
}

\section{Gülsüm ALKAN"II Halil Güner SEFEROĞLU'(iD}

\begin{abstract}
' Adnan Menderes Üniversitesi, Ziraat Fakültesi, Bahçe Bitkileri Bölümü, Aydın.
Öz: Bu çalıșma, 2009-20II yılları arasında Adnan Menderes Üniversitesi Ziraat Fakültesi Bahçe Bitkileri Bölümüne ait meyve koleksiyon bahçesi ve Aydın’a bağlı Dalama Beldesinde yürütülmüștür. Bu araștırmada, çöğür anacı üzerine așilı Ferraduel, Ferragnes, Nonpareil, Primorskii, Texas ve Tuono çeșitleri kullanılmıștır. Her çeșide ait ağaçlar üzerinde uygulama olarak boğma ve dal açma uygulamaları yapılmıștır. Yaprak ve sürgünlerde biyokimyasal olarak klorofil, toplam șeker, toplam nișasta, toplam karbonhidrat ve amigdalin içerikleri belirlenmiștir. Değerlendirmeler sonucunda, klorofil miktar ve yoğunluğu bakımından; 'Tuono' çeșidinin öne çıktığı, dal açma ve boğma uygulamasının daha fazla dikkat çektiği görülmüștür. Toplam șeker ve nișsata miktarında ise dal açma uygulamasının yapılmıș olduğu 'Ferragnes' ve 'Ferraduel' çeșitlerinin en yüksek değerlere sahip olduğu tespit edilmiștir. Amigdalin miktarı açısından her iki lokasyonda boğma, çeșit olarak; meyve koleksiyon bahçesinde Primorskii, Dalama lokasyonunda ise Ferraduel öne çıkmıștır.
\end{abstract}

Anahtar Kelimeler: badem, klorofil, toplam șeker, toplam nișasta, amigdalin

The Biochemical Characteristics of Some Almond Cultivars in Aydın Ecology

Abstract: This research was carried out in fruit science collection orchards in Horticulture Department, Agriculture Faculty, Adnan Menderes University in Aydın province and almond parcels in Dalama county between 2009 and 201 I years. Texas, Nonpareil, Ferraduel, Ferragnes, Primorskii ve Tuono cvs. which is grafted on almond seedlings were used. The applications of ringing (girdling effect) and making wider branch angle have been carried out. Chlorophyll, total sugar, total starch, total carbohydrate and amygdalin contents as biochemical have been determined on leaves and shoots. As a result of evaluations, when the amount of chlorophyll and its density were evaluated, Tuono cv. and ringing and wider branch angle applications became more noticeable. Ferraduel, Ferragnes cvs. and the plants made wider branch angle application had the highest total sugar and total starch. Ringing in both location, Primorskii cv. in fruit collection orchards and Ferraduel cv. in Dalama country had the highest amygdalin contents. Keywords: almond, chlorophyll, total sugar, total starch, amygdalin

\section{GiRis}

Badem, Anadolu'nun en eski meyve türlerinden birisidir. Ancak ülkemizde bademe öteki meyve türleri kadar önem verilmemekte, genellikle bahçelerin kenarında sınır ağacı olarak yetiștirilmektedir. Erken çiçek açan bir meyve türü olan bademde ilkbahar geç donları çiçeklere zarar verdiğinden badem ağaçlarından düzenli bir șekilde ürün alınamaması da ticari badem yetiștiriciliğinin gelișmemesinde önemli bir etkendir.

Badem yetiștiriciliğinde ilkbaharda yașanan don olayları, özellikle çiçek ve körpe çağla döneminde çok önemlidir. Çiçeklenme zamanında -4 ile $-5{ }^{\circ}$ C'ye dayanabilen çiçekler, körpe çağla döneminde $-\mathrm{I,5}{ }^{\circ} \mathrm{C}$ 'de zarar görürler. Dona dayanım bakımından klonlar arasında büyük farklar görülmektedir (Özkarakaș, 2005).

Birçok tür ve çeșitte olduğu gibi bademde de çiçeklenme zamanları farklılıklar gösterebilmektedir. Badem çiçeklenme sezonu uzun olan türlerden biridir ve çiçeklenme tarihleri yıllara göre değișebilmektedir. Badem, vegetasyon döneminde ilk çiçek açan tür olduğu için, yetiștiriciliği ilkbahar donlarının riskli olduğu bölgelerde sınırlanabilmektedir (Gülcan, 1976). Dolayısıyla, geç çiçeklenen çeșitlerin geliștirilmesi badem ıslah programlarının en önemli hedefi haline gelmiștir. Bununla birlikte, geç çiçeklenme uygun yüksek sıcaklıklarda daha yüksek tozlanma ve döllenme imkanı sağlamaktadır (Gülcan, 1976; Socias ve ark., 1999 Badem çeșitleri; erken, orta ve geç çiçeklenenler olarak gruplandırılmaktadır. Ülkemizde kurulacak olan badem bahçelerinde yöredeki ilkbahar geç donları dikkate alınarak özellikle geç çiçeklenen çeșitlerin (Ferragnes,
Ferraduel, Cristomorto vb) seçilmesi zorunludur (Anonim, 2012a).

Ayrıca, diğer meyve türlerinde olduğu gibi, bademde de gençlik kısırlığı mevcuttur. Gençlik kısırlığı süresini kısaltmak için yapılan boğma ișleminde amaç, bitkilerde hareket halinde bulunan yedek besin maddelerinin gerek ilkbaharda ve gerekse vejetasyon periyodunda ağaçların çeșitli kısımlarına tașınmasını güçleștirmek veya engellemek ve böylece belli organlarda asimilat maddelerinin yığılmasını sağlamaktır. Bu hususta meyvecilik pratiğinde bilezik alma, boğma ve kertikleme gibi ișlemler uygulanır. Kalın dallarda ve gövdede boğma daha emin ve aynı zamanda etkisi bilezik alma gibi șiddetli olmayan daha ılımlı bir teknik tedbirdir. Boğmanın etkisi bilezik almaya göre daha geç bașlar, fakat istenirse uzun yıllar sürdürülebilir. Boğmanın gereksizleștiği durumlarda boğma teli kesilir. Böylece ağaç genișliğine büyürken buradaki iletken dokuda engelin kalkması ile daha iyi iș görebilecek bir duruma girer. Boğmada ağacın dokuları yaralanmaz. Bu nedenle, sert çekirdekli türlerin ağaçlarında da korkusuzca uygulanabilir. Yaralanma söz konusu olmadığı için boğma ana dallarda ve gövdede olumsuz bir etkiden korkulmadan uygulanabilir (Anonim, 20I2b). Dal açısı olușturmada ise, haziranın ortasından

Sorumlu Yazar: gkarakaya@adu.edu.tr

Bu çalısma doktora tezi ürünü olup, Adnan Menderes Üniversitesi Bilimsel Araștırma Projeleri tarafindan desteklenmiștir.

Geliș Tarihi: 19 Ocak 2018

Kabul Tarihi: 4 Haziran 2018 
sonra dik büyüyen dalları lider ile $45-60^{\circ}$ açı yapacak șekilde açmak gerekmektedir. Bu amaçla, eğer dal küçükse kürdan, çamașır mandalı, biraz büyükse çıtalar, çubuklar veya çamașır mandalına bağı beton ağılıklar kullanılabilir. Açı genișletmede kullanılan bu materyaller ağustos ayı sonunda çıkartılmalıdır (Anonim, 2008). Bitkilerin yayılıșları ve gruplașmalarında arazinin morfolojisi, iklim ve toprak özellikleri önemli yer tutar. Bu özellikler bitki örtüsünün șekillenmesini sağladığı gibi bitkilerin biyolojik aktivitesini de düzenler. Bitkilerin yapraklarında bulunan klorofil miktarı hayat formu, mevsim, ıșık koșulları gibi değișik faktörlerin etkisi ile geniș bir değișkenlik göstermektedir. Klorofil miktarı üzerinde bu faktörlerin kombine etkisi söz konusudur. Bitkilerin vejetasyon dönemlerinin devam ettiği mevsimlerdeki klorofil miktarlarının tespiti, araștıııcılara klorofil miktarlarını etkileyen faktörlerin belirlenmesinde temel teșkil etmektedir. Klorofil miktarındaki farklılașmalar, direkt olarak bitkilerde üretilen karbonhidrat ve fotosentezin yoğunluğuna etki etmektedir (Kutbay ve Kılınç, 1992).

Klorofil yoğunluk ve miktarını belirlemek için yapılan spektroradyometrik çalıșmalarda, ölçülen yansıma değerlerinin logaritması, I. ve 2. türevi gibi yeni veri türetmeleri kullanılabilmektedir. Ayrıca iki farklı dalga boyunda ölçülmüș yansıma değerlerinin birbirlerine oranlanması ile elde edilen indisler de kullanılmaktadır. NDVI (Normalized Difference Vegetation Index), DVI (Difference Vegetation Index), IPVI (Infrared Percentage Vegetation Index), RVI (Ratio Vegetation Index), SIPI (Structure Intensive Pigment Index), PSRI (Plant Senescene Reflectance Index), PRI (Phothochemical Peflectance Index), SR680, SR705, mSR705, mND705, Red-Edge, Cl (Curvature Indeks), RI, R2, R3, R4, R5 en yaygın kullanılan indislerdir (Anonim, 20/2c). NDVI yöntemi, sadece doğada bulunan bitki yansımalarının değerlendirilmesidir. Bitkiler, kızılötesi (NIR, near infrared) bantta yüksek, görünür kırmızı bantta düșük yansıma değeri verir. Böylece, bitki varlığını ön plana çıkarmak için NDVI kullanılır. Dolayısıyla, NDVI bitkilerdeki klorofil bolluğunun da bir ölçüsüdür (Anonim, 2012d).

Bitkilerdeki siyanojenik bileșiklerin belirlenmesinde genellikle yüksek basınçı sıvı kromatografisi (HPLC) yöntemi uygulanır. Yapılan analizlerde tanenler ve diğer pigmentler gibi, gözenekler arasında müdahele edilen bileșiklere, özellikle köklerde ve yapraklarda karșılașılmıș ve metot, badem ağacı dokularındaki amigdalin (Dmandelonitrile â-D-gentiobioside) ve prunasin (Dmandelonitrile â-Dglucoside) siyanojenetik glikozitlerinin, sırasıyla polivinilpirolidon veya aktif karbon gibi tutucular kullanılarak köklerden ya da yapraklardan ekstrakte edilmesini sağlamıștır. Köklerdeki prunasin analizi için bir 92
Hypercarb kolonunun avantaj olduğu belirlenmiștir. Yapılan çalıșmalar sonucunda, prunasinin badem ağacı köklerinde bulunan tek siyanoglikozit olduğunu da kanıtlar niteliktedir (Berenguer-Navarro ve ark., 2002).

Ekonomik değeri oldukça yüksek bir meyve türü olan bademde, ilkbahar donlarının riskli olduğu bölgelerde geç çiçeklenen çeșitleri kullanarak zararlanmaları ortadan kaldırmak veya en aza indirmek, badem yetiștiriciliğini geliștirmek ve de yabancı ülkelerdeki modern yetiștiricilik standartlarına ulașmak ülkemiz için hedef olmalıdır. Badem yetiștiriciliği açısından ekolojik șartlar da gözönüne alındığında, Aydın yöresine uygun çeșitler ve uygulamaların belirlenmesine yönelik yürütülmüș bu araștırmada; çeșitlerin adaptasyonları ve fidanlarının erken meyveye yatma uygulamalarına verdikleri tepkiler araștırılmıștır. Elde edilen sonuçların, badem için uygun bir ekolojik yapıya sahip olan Aydın'da yetiștiriciliğin geliștirilmesine katkı sağlayabileceği düșünülmektedir.

\section{MATERYAL ve YÖNTEM}

Araștırma, Adnan Menderes Üniversitesi Ziraat Fakültesi Bahçe Bitkileri Bölümüne ait yaklașık $50 \mathrm{~m}$ rakımlı deneme parselinde ve Alpler Ziraat Aletleri A.Ș.'ne bağlı yaklașı $300 \mathrm{~m}$ rakımlı Dalama bölgesinde bulunan arazide olmak üzere farkı iki lokasyonda yürütülmüștür. Çalıșmada, badem çöğürü üzerine așilı "Texas", "Nonpareil", "Ferraduel", "Ferragnes", "Primorskii", ve "Tuono" badem çeșitleri (2 yașlı) (Prunus dulcis (Miller) D.A. Webb.) projenin bitkisel materyallerini olușturmaktadır.

Deneme, 6 farklı çeșit 6 ayrı sırada olmak üzere kurulmuș ve bölünmüș parseller deneme desenine göre 3 tekerrürlü olarak yürütülmüștür. Her bir tekerrürde 3'er bitki olacak șekilde her bir çeșitten 9 bitki kullanılmıștır.

Çalıșmada temmuz, ağustos, eylül, ekim ve kasım aylarında her bir bitki için 4 farklı yöndeki sürgünden 3'er yaprakta PlantPen NDVI 300 cihazı ile klorofil yoğunluğuna bakılmıștır.

Sürgün örneklerinde toplam karbonhidratları olușturan toplam șeker (\%) ve toplam nișasta (\%) değerlerini saptamak amacıyla, spektrofotometrik bir yöntem olan "anthrone yöntemi” kullanılmıștır (Kaplankıran, 1992).

Amigdalin analizi: 201 I yılı temmuz ayında tekerrürlere ait fidanlardan alınan yapraklarda Dicenta ve ark. (2002)'ye göre amigdalin analizi yapılmıștr. Buna göre 0.2 g yaprak örneği $10 \mathrm{ml}$ metanol içinde oda sıcaklığında 12 saat bekletilmiștir. Daha sonra her bir örneğe $0.1 \mathrm{~g}$ aktif karbon (Norit CNR II5) koyulmuștur. Hazırlanan örnekler otomatik pipet yardımıyla cam tüpe aktarılmıștır. Sonra her bir örnekten $0.5 \mathrm{ml}$ çekilerek daha küçük cam tüplere aktarımıștır. Aktarma ișlemi sırasında $0.45 \mu^{\prime}$ 'luk filtrelerden yaralanılmıștır. Bu örneklerin de üzerine $0.5 \mathrm{ml}$ su ilave edilmiștir ( $\mathrm{pH}: 2.7)$. HPLC yöntemi için Kajiwara ve ark. (1983) prosedürü kullanılmıștır. Kromatografi șartları; mobil faz su 90:10 
(H2O:ACN), kolon: Waters Symmetry Cl8 $(250 \mathrm{~cm}$ x4.6 mm) $5 \mu$, akıș hızı: $1.3 \mathrm{ml} / \mathrm{d}$., enjeksiyon miktarı: 25 ml, kolon ısısı: $40^{\circ} \mathrm{C}$, dedektör: DAD $220 \mathrm{~nm}$.

Klorofil analizi: Bitkiye renk veren pigmentler spektrofotometrik yöntemlerle okunmuș ve Witham ve ark.. (197I)'e göre belirlenmiștir.

Her çeșitte 3 adet kontrol bitki kullanılmıș, uygulama olarak boğma (çiçeklenmeden önce her çeșitten 3 bitkinin gövdesinde, așı yerinin $50 \mathrm{~cm}$ üzerinden plastik bağlarla uygulanmıștır) ve dal açısı olușturma (45-60 açı olușturacak șekilde mayıs ayında her çeșitten 3 bitkide 3'er adet dal açma aparatı takılmıș ve bunlar ağustos ayı sonunda çıkarılmıștır) yapılmıștır. İncelenen karakterlere ait veriler için, çeșitler ana parsel, uygulamalar alt parsel olacak șekilde bölünmüș parsellerde (split plot) tesadüf blokları deneme desenine göre 3 tekerrürlü olarak
ALKAN G, SEFEROĞLU H G varyans analizi uygulanmıștır. Önemli bulunan uygulamalar için LSD \%5 karșılaștırma testi kullanılmıștır.

\section{BULGULAR ve TARTIȘMA}

Meyve koleksiyon bahçesindeki deneme ağaçlarında toplam șeker miktarları bakımından kontrolde Ferragnes ve Primorskii, boğma uygulamasında Nonpareil, dal açma uygulamasında Tuono çeșidinin en yüksek değerlere sahip olduğu tespit edilmiștir. Dalama lokasyonundaki badem çeșitlerine ait deneme ağaçlarında da toplam șeker miktarları bakımından kontrolde Ferragnes ve Primorskii, boğma uygulamasında Nonpareil, dal açma uygulamasında ise Tuono en dikkat çeken çeșitler olarak belirlenmiștir. Çeșit ortalamalarında Ferragnes ve uygulama ortalamalarında ise dal açma uygulaması en büyük değere sahip olmuștur (Șekil I, 2).

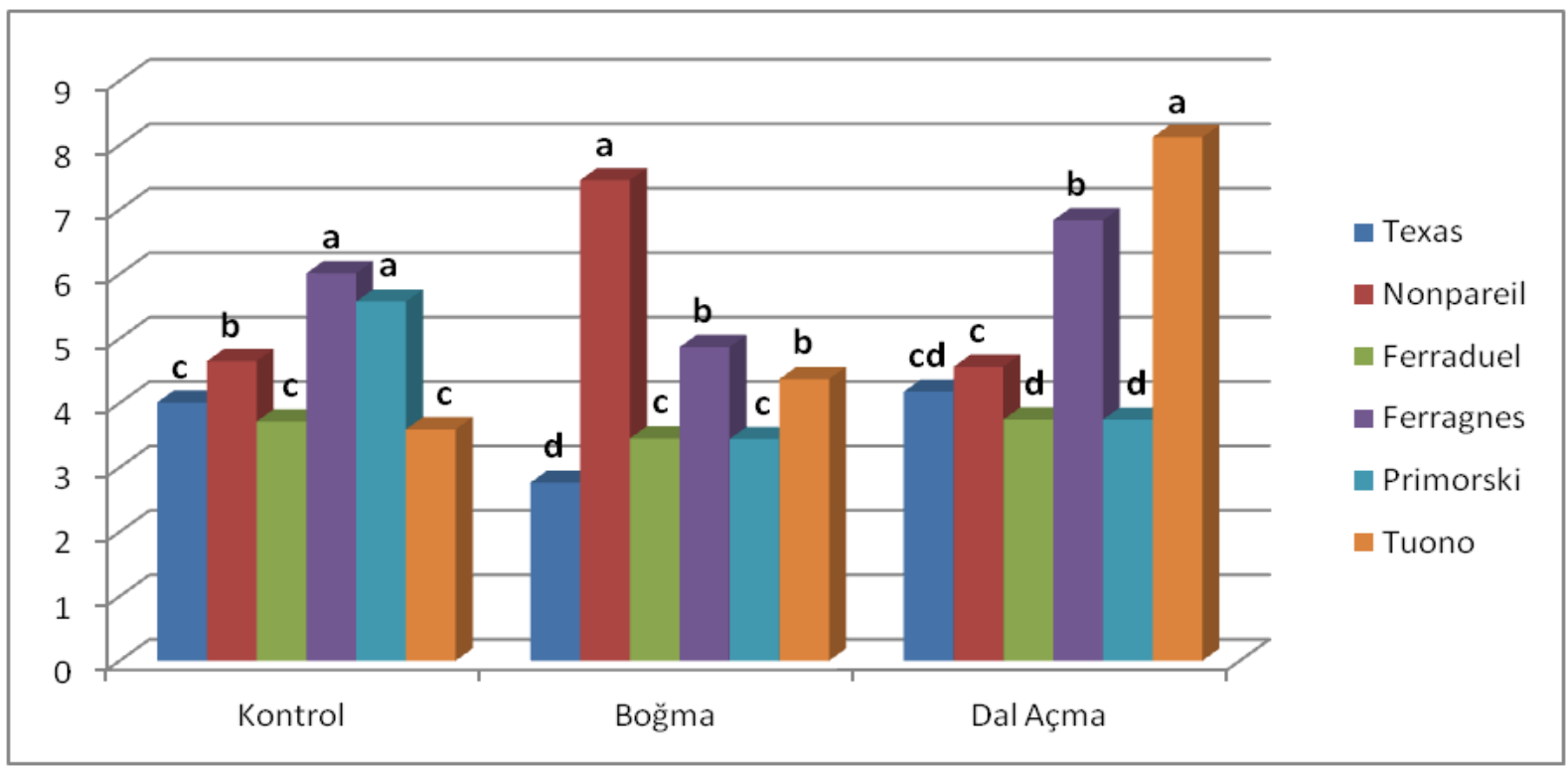

Șekil I. Meyve koleksiyon bahçesine ait toplam șeker miktarları (g/l00 g)

Sabancı ve Çağlar'ın (2005), kușaklı boğma uygulanan ve kontrol ağaçların sürgün uzunluğu, çapı, uç tomurcuk iriliği ve boğum arası uzunlukları ile sürgünlerin toplam ve indirgen șeker içerikleri üzerine yaptıkları araștırmada da kușaklı boğma uygulaması ceviz sürgünlerinin kısalmasına, kalınlașmasına, boğum aralıklarının daralmasına ve uç tomurcukların irileșmesine yol açmıștır.

Denemeye ait meyve koleksiyon bahçesinde kontrolde ve dal açma uygulamasında Ferraduel, boğma uygulamasında Primorskii en fazla toplam nișasta miktarına sahiptir. Çeșitler arasında Ferraduel, uygulamalar arasında ise dal açma ilk sırada yer almıștır. Diğer lokasyon olan Dalama'da kontrolde, dal açma uygulamasında ve çeșitler arasında Ferraduel, boğma uygulamasında Primorskii en fazla değere sahip olmuștur. Toplam șeker miktarı bakımından uygulamalar arasında dal açma ilk sırada yer almıștır (Șekil 3, 4).

Araștırmada toplam karbonhidrat miktarı yönünden meyve koleksiyon bahçesinde uygulamalar arasında dal açma, çeșitler arasında da Ferragnes dikkat çekmiștir. Dalama lokasyonunda; kontrolde ve dal açma uygulamasında Ferraduel ve Ferragnes, boğma uygulamasında Primorskii en fazla karbonhidrat içeriğine sahip olmuștur. Çeșitler arasında toplam karbonhidrat miktarı bakımından, en fazla içeriğe Ferraduel çeșidinin sahip olduğu; uygulamalar arasında da dal açma uygulamasının toplam karbonhidrat miktarı bakımından ilk sırada yer aldığı belirlenmiștir (Șekil 5, 6). 


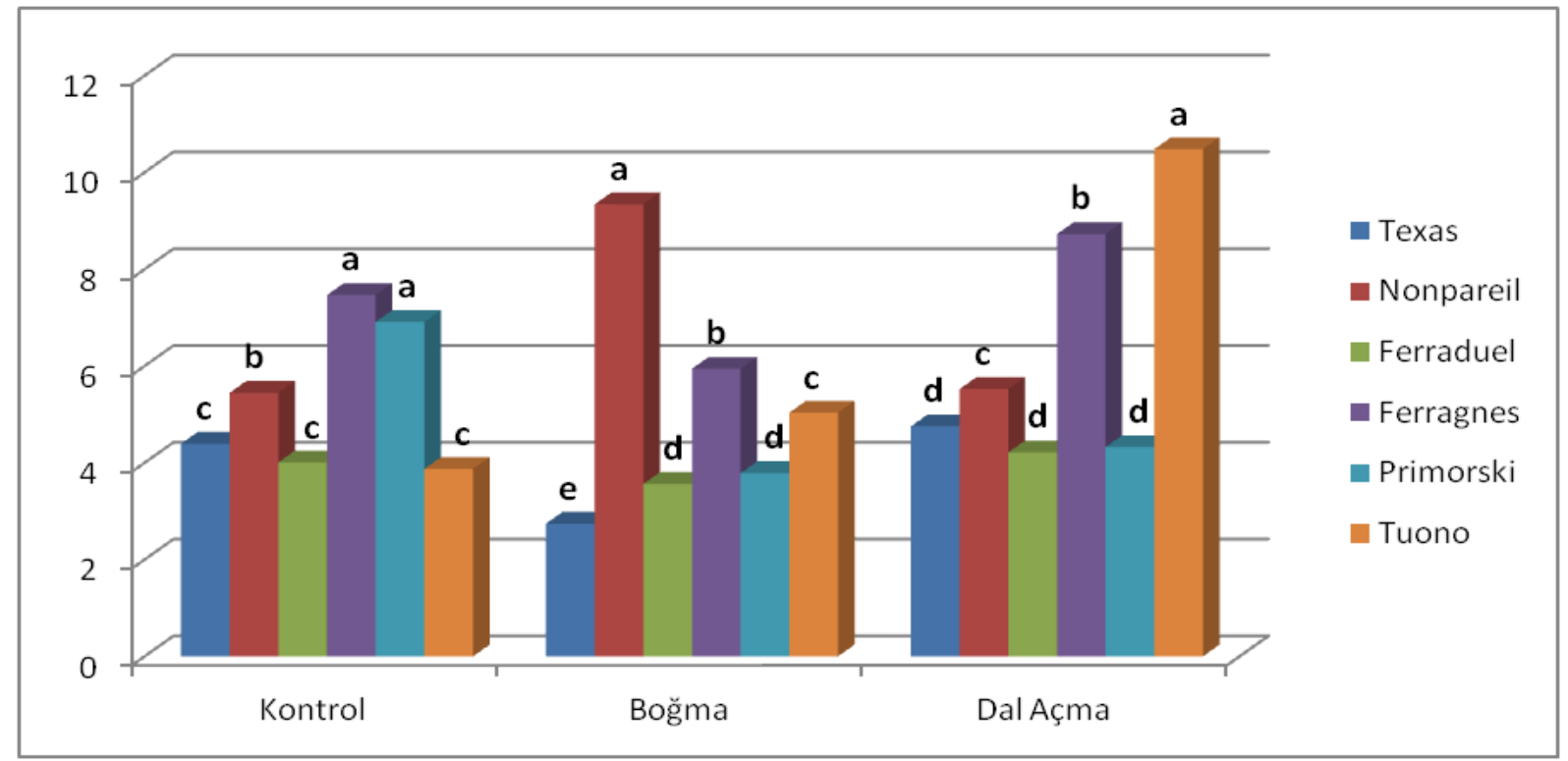

Șekil 2. Dalama lokasyonuna ait toplam șeker miktarları (g/l00 g)

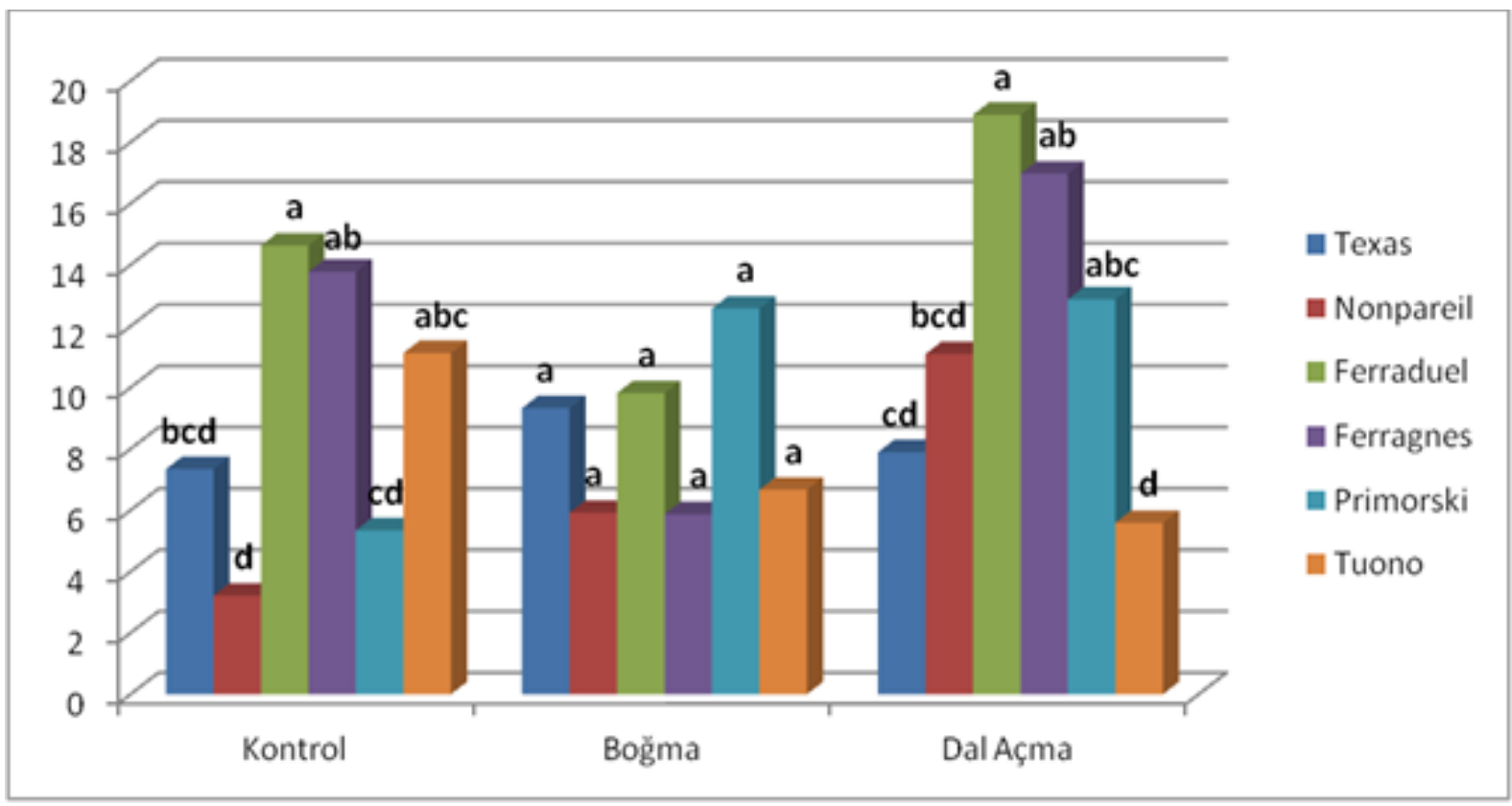

Şekil 3. Meyve koleksiyon bahçesine ait toplam nişasta miktarları (g/l00 g) 


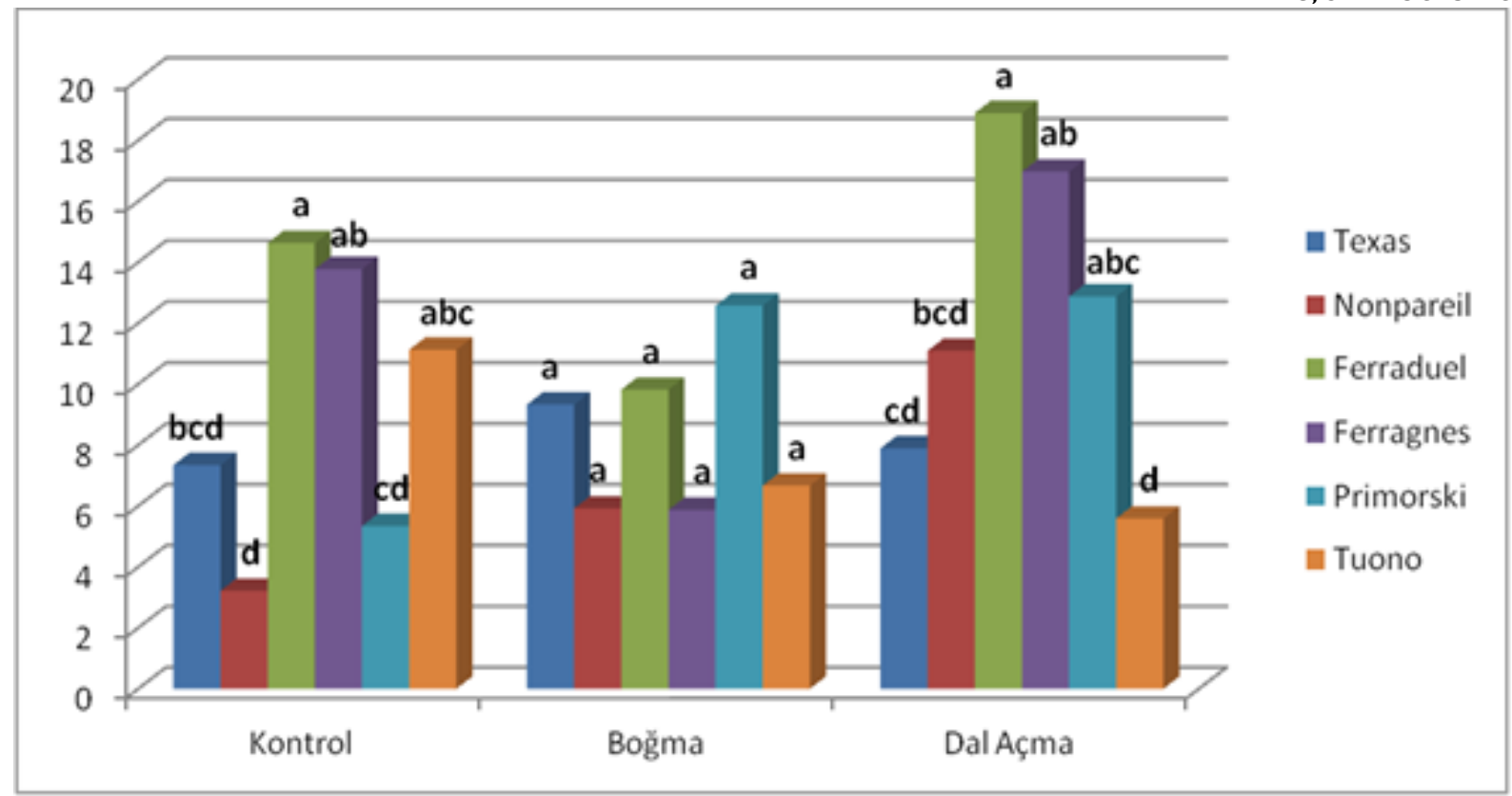

Șekil 4. Dalama lokasyonuna ait toplam nișasta miktarları (g/l00 g)

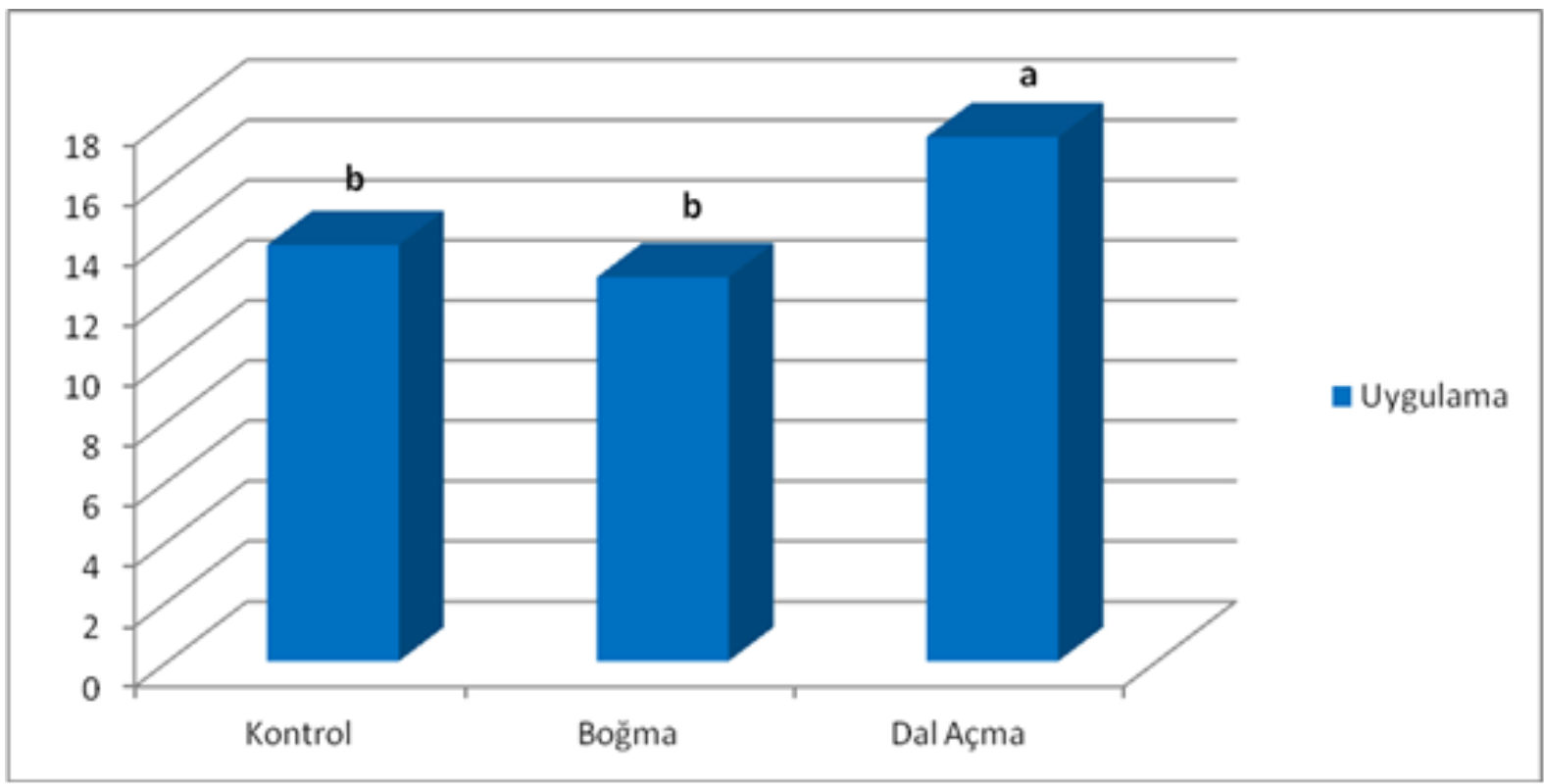

Șekil 5. Meyve koleksiyon bahçesine ait toplam karbonhidrat miktarları (g/l00 g) 


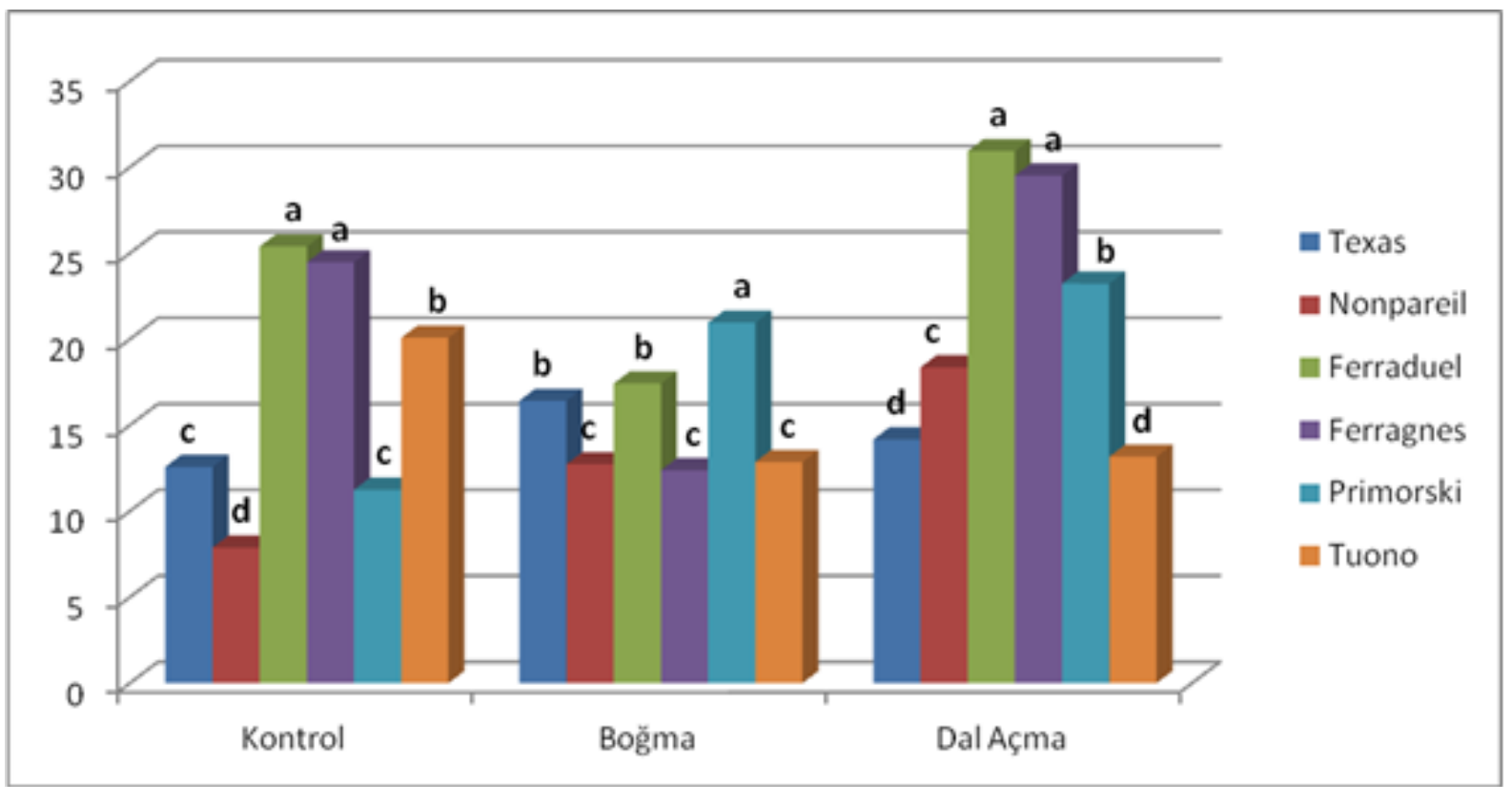

Șekil 6. Dalama lokasyonuna ait toplam karbonhidrat miktarları (g/l00g)

$\mathrm{Bu}$ değerlendirmelere göre toplam șeker içeriği bakımından çeșitler arasında Feragnes, toplam nișasta içeriği bakımından ise Ferraduel en dikkat çeken çeșitler olmuștur. Toplam karbonhidrat miktarı anlamında ise meyve koleksiyon bahçesinde Ferragnes, Dalama lokasyonun da ise Ferraduel öne çıkan çeșitler olmuștur. Her iki lokasyonda da dal açma uygulaması en yüksek değerlere sahip olan uygulama olarak kendini göstermiștir.
Çalıșmada; amigdalin miktarı bakımından koleksiyon bahçesinde uygulamalarda, boğma uygulaması (4I.173 mikgram/g), ve çeșitler arasında ise Primorskii (6I.008 mikgram/g) birinci sırada yer almıștır. Dalama lokasyonunda ise çeșitler arasında Ferraduel (45.90I mikgram/g) en yüksek amigdalin değerini vermiștir. Sonuçlar istatistiki olarak varyans analizinde önemsiz çıkmıștır (Șekil 7, 8).

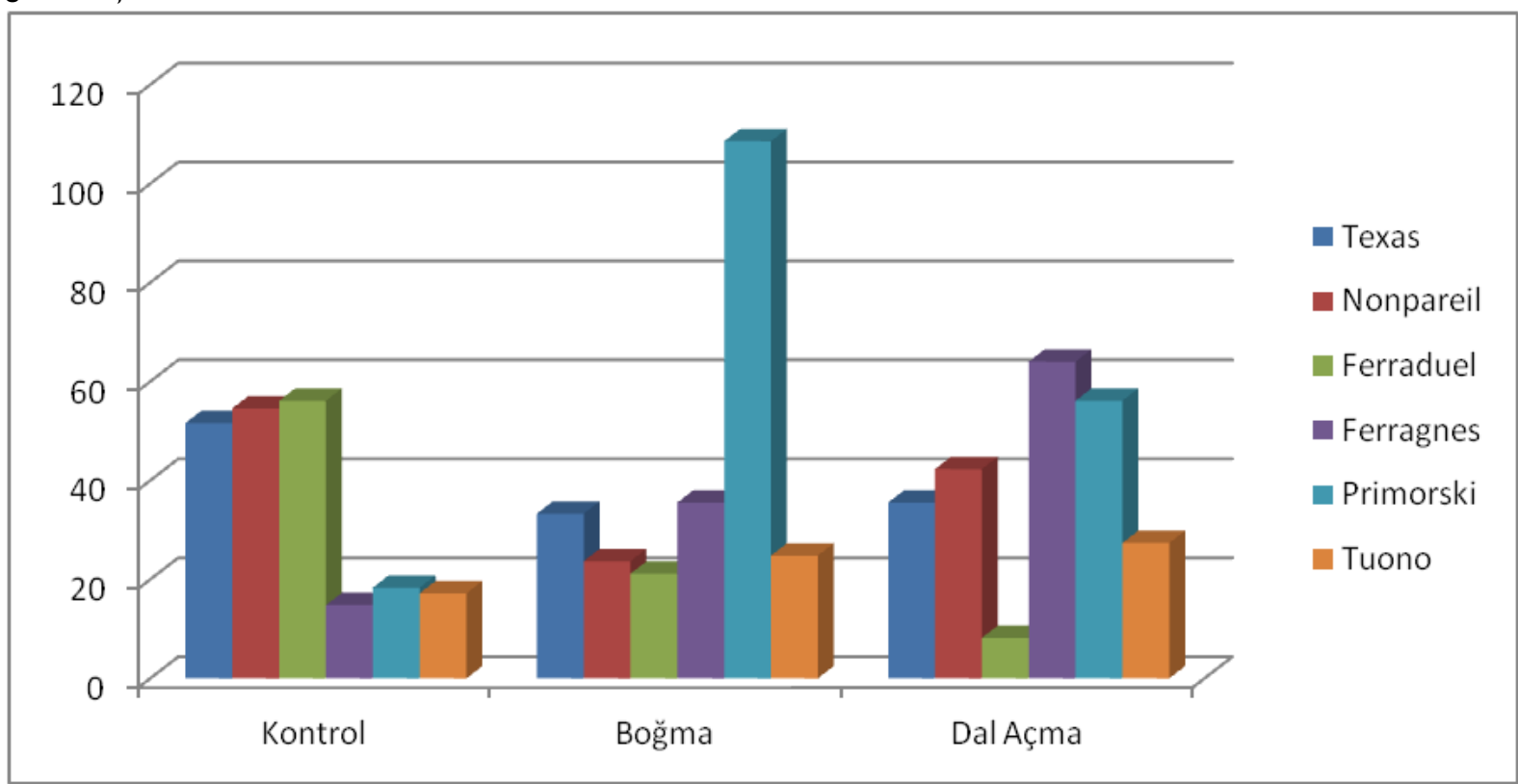

Șekil 7. Meyve koleksiyon bahçesine ait amigdalin miktarları (mikgram/g) 


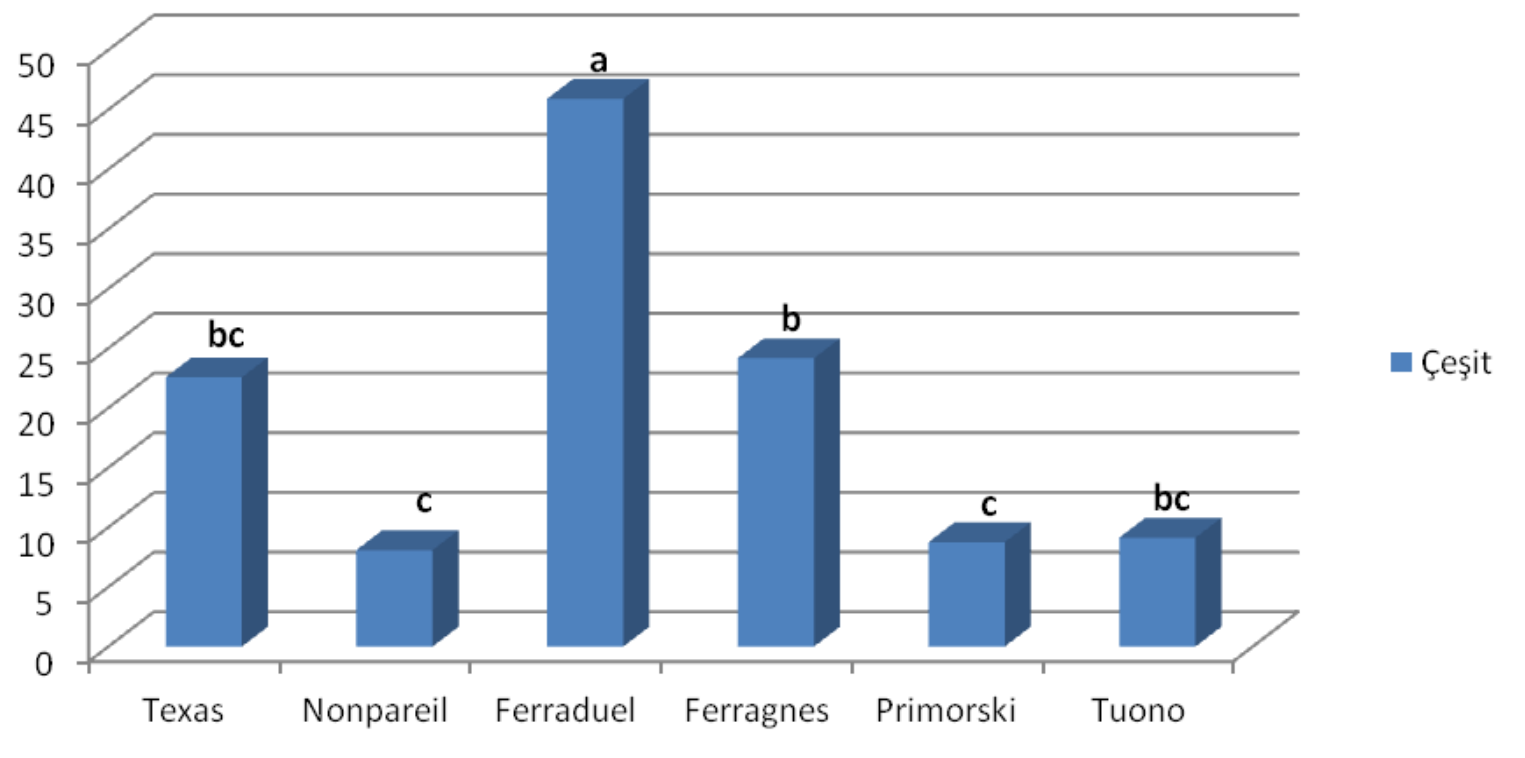

Șekil 8. Dalama lokasyonuna ait amigdalin miktarları (mikgram/g)

$\mathrm{Bu}$ sonuçlara bakıldığında denememizde bulunan

çeșitlerinin daha yüksek değerlere sahip olduğu fidanlarımızda amigdalin miktarının düșük olduğu tespit edilmiștir.

Klorofil miktarı bakımından, 3 yılla ait ortalamalarda meyve koleksiyon bahçesinde Tuono çeșidi, Dalama lokasyonunda da Primorskii, Tuono ve Ferraduel belirlenmiștir. Klorofil yoğunluk ve miktarları bakımından kontrol grubunun öne çıktığı görülmektedir (Șekil 9, I0, II, 12). Meyve koleksiyon bahçesinde ortalamalar arasındaki farklar incelendiğinde istatistiki olarak önemsiz çıkmıștır (Șekil II).

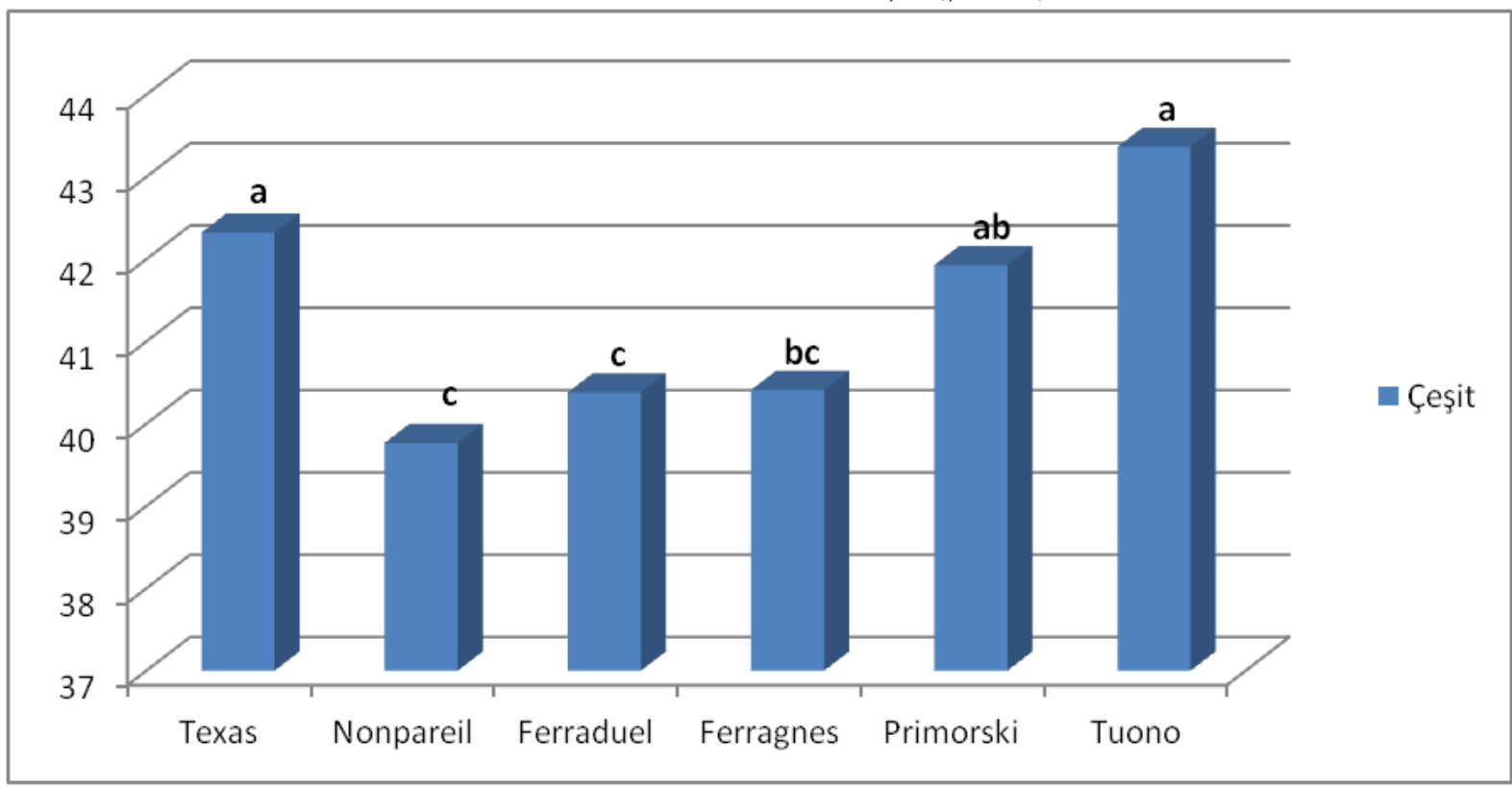

Șekil 9. Meyve koleksiyon bahçesine ait 3 yıllık ortalama klorofil yoğunlukları 


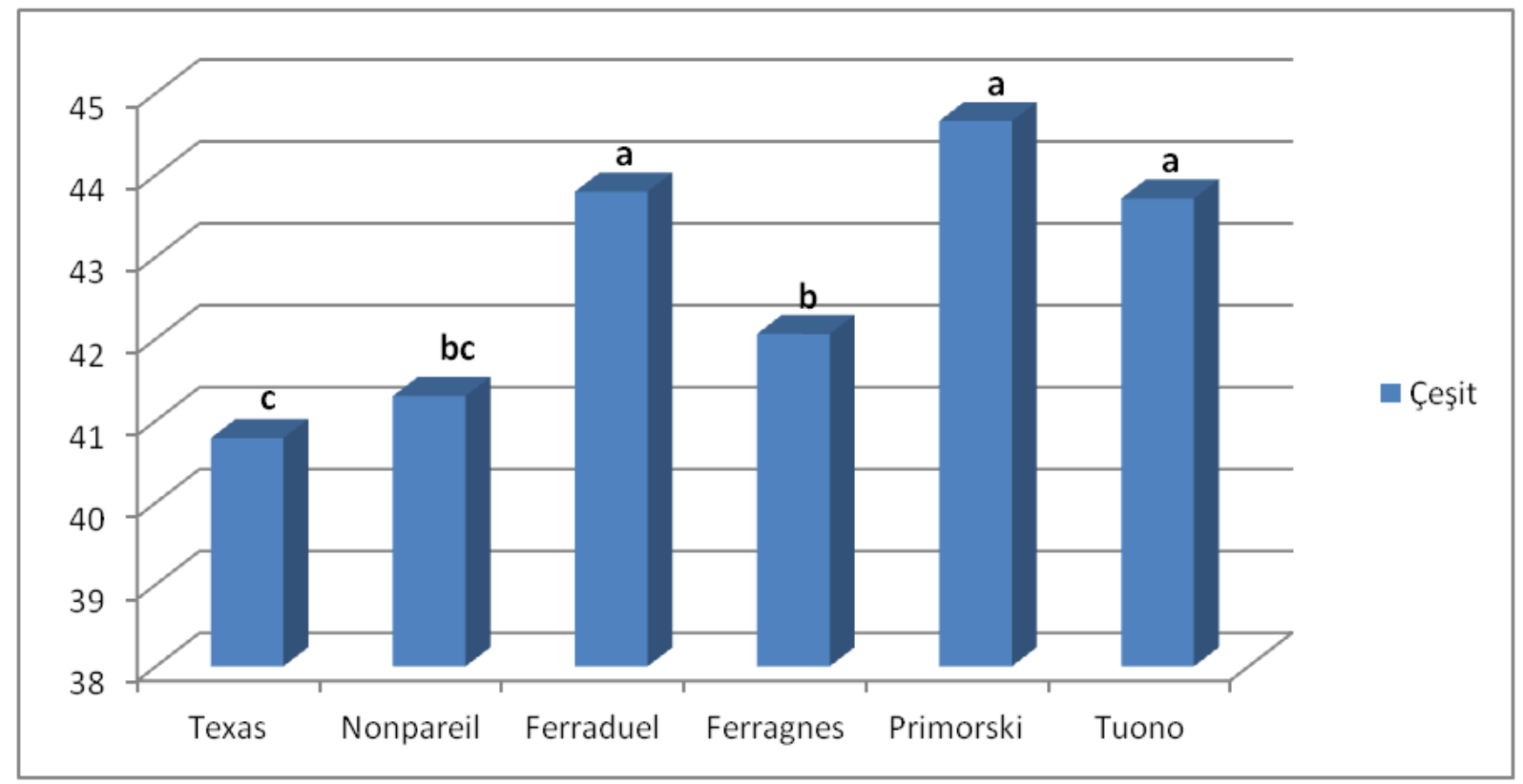

Șekil 10. Dalama lokasyonuna ait 3 yıllık ortalama klorofil yoğunlukları

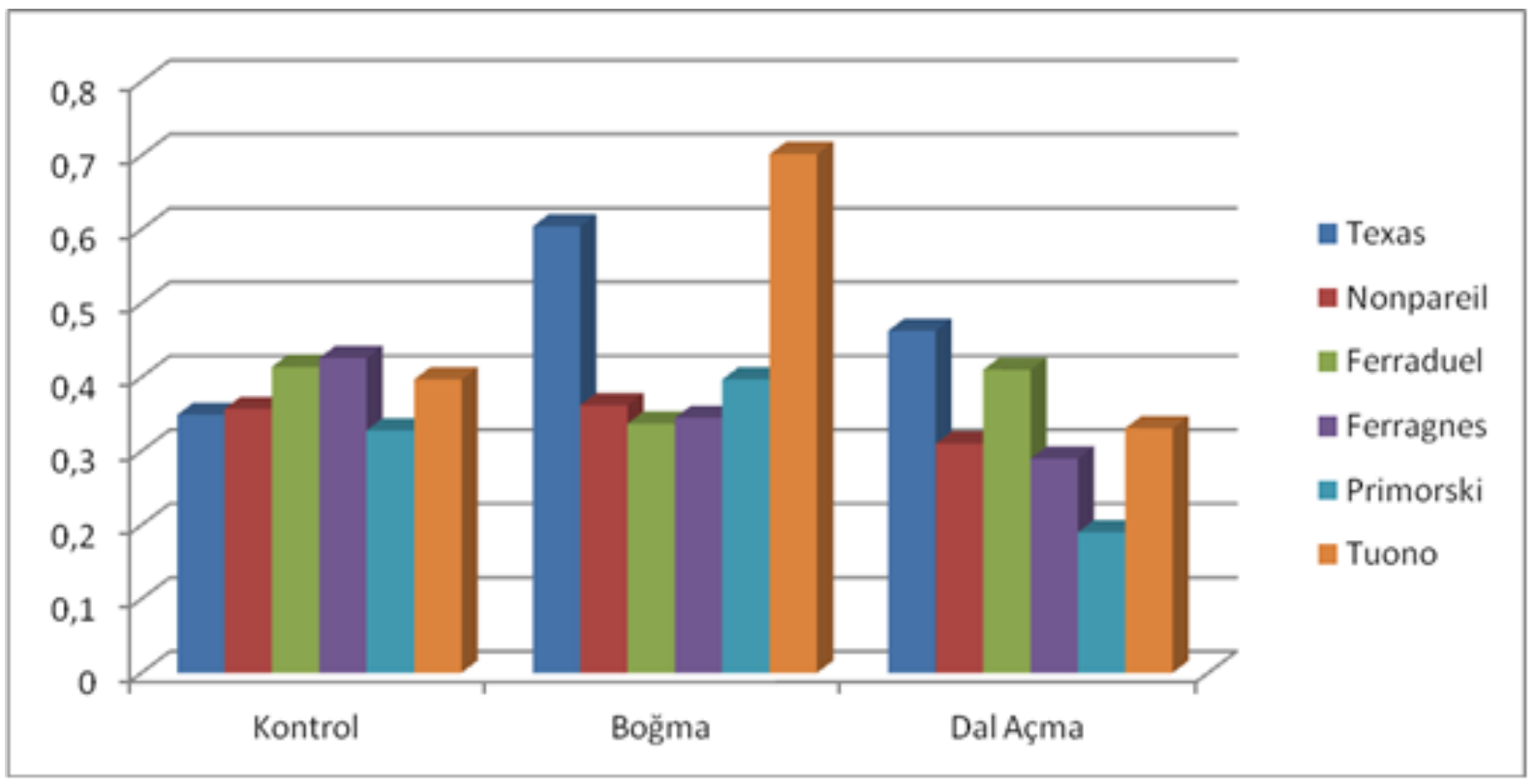

Șekil I I. Meyve koleksiyon bahçesine ait 3 yıllık ortalama klorofil miktarları (mg..$\left.^{-1}\right)$ 


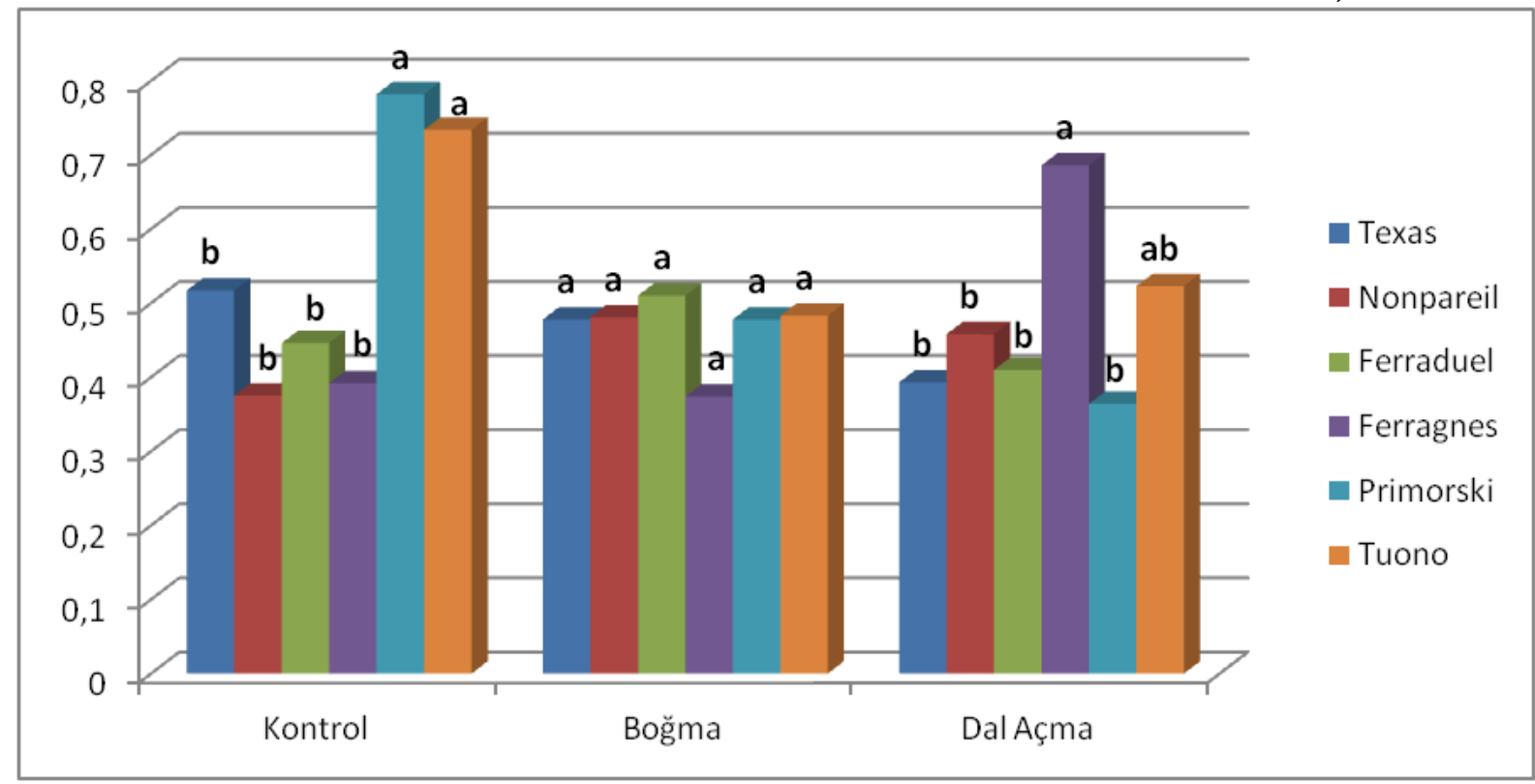

Șekil I 2. Dalama lokasyonuna ait 3 yıllık ortalama klorofil miktarları (mg.g-')

\section{SONUÇ}

Tüm değerlendirmeler ıșığında, denememizde yapılan dal açma ve boğma uygulamalarının kontrole göre daha önemli sonuçlar verdiği, çeșitler toplam șeker bazında Tuono çeșidinin, toplam nișasta bakımından ise Ferraduel çeșidinin diğerlerine göre daha fazla dikkat çektiği belirlenmiștir. Uygulama olarak her iki parametre açısından dal açma uygulaması yapılan fidanlarda sonuçlar daha fazla çıkmıștır. Özellikle dal açma uygulamasının fotosenteze olumlu katkıda bulunup karbonhidrat miktarını arttırdığı gözlenmiștir. Klorofil yoğunluk ve miktarı açısından meve koleksiyon bahçesinde Tuono çeșidinden, Dalama lokasyonunda ise Primorski çeșidinden daha yüksek sonuçlar elde edilmiștir. Lokasyonlar bakımından ise, birçok özellik açııından Dalama bölgesinde bulunan lokasyona ait değerlerin, meyve koleksiyon bahçesine ait değerlere göre daha yüksek olduğu ve buna bağlı olarak öne çıktığı anlașılmıștır. Söz konusu uygulamaların karbonhidrat miktarını arttırmada etkili olduğu ve dolayısıyla da bitkilerde tomurcuk olușumuna katkıda bulunacağı sonucuna varılmıștır.

\section{KAYNAKLAR}

Anonim (2008) http://www.bahcesel.com/koseyazilari/ziraat-muhendisi-s-murat-sarac/7237-meyveagaclarinda-yaz-budamalari.html. Erișim tarihi: 28.07.20I2

Anonim (2012a) http://www.fidan.web.tr/badem _ fidani/dollenme.htm. Son güncelleme: II.06.20I2.

Anonim (2012b) http://volkanderinbay.com/tarimnet/ gmeyve.asp?konuno=3. Erișim tarihi: 28.07.2012

Anonim (2012c) http://kisisel.sdu.edu.tr/ blogicerik.aspx?!D=a7c2d9f9-407a-4e02-a60f-

56b525f4eadc. Erișim tarihi: 28.07.2012.
Anonim

(20/2d)

http://www.poyrazlab.com/ content/view/2/I/ Erișim tarihi: 27.07.2012

Berenguer-Navarro V, Giner-Galvaän RM, Graneä Teruel N (2002) Chromatographic determination of cyanoglycosides prunasin and amygdalin in plant extracts using a porous graphitic carbon column. Journal of Agricultural and Food Chemistry 50: 69606963.

Gülcan, R (1976) Seçilmiș badem tipleri üzerinde fizyolojik ve morfolojik araștırmalar. Ege Üniversitesi Ziraat Fakültesi Yayınları No: 310, İzmir, 72s.

Dicenta F, Martínez-Gómez P, Grané N, Martín ML, León A, Cánovas, JA, Berenguer V (2002) Relationship between cyanogenic compounds in kernels, leaves, and roots of sweet and bitter kernelled almonds. Journal of Agricultural and Food Chemistry, 50: 2149-2152.

Kajiwara N, Tomiyama C, Ninomiya T, Hosogai Y (1983) Determination of amygdalin in apricot kernel and processed apricot products by high performance liquid chromatography. Journal of the Food Hygienic Society of Japan 24(I): 42-46.

Kaplankıran, M (1992) Bitki dokularında karbonhidrat analizleri için spektrofotometrik yöntemler. Çukurova Üniversitesi Ziraat Fakültesi Dergisi 7(3): 167-176.

Kutbay, HG, Kılınç M (1992) Bazı bitkilerdeki klorofil a ve klorofil b içeriklerinin mevsimsel değișimi. F.Ü. XI. Ulusal Biyoloji Kongresi Bildirileri, (24-27 Haziran 1992), s: 195-202, Elazığ.

Özkarakaș, I (2005) Badem yetiștiriciliği. Ege Tarımsal Araștırma Enstitüsü Müdürlüğü, 
http://www.bahce.biz/bitki/meyve/badem.htm./8.10.2 005, İzmir. Erișim tarihi: 30.07.2012.

Sabancı A, Çağlar S (2005) Cevizlerde kușaklı boğma uygulaması üzerine bir araștırma. KSÜ Fen ve Mühendislik Dergisi 8(2): I35-I39.
Socias Company R, Felipe AJ, Aparisi JG (1999) Genetics of late blooming in almond. Acta Horticulturae, 484: 26I-26.

Witham FH, Bladydes DF, Delvins RM (197I) Experiment in Plant Physiology. Van Nostrand Reinhold, New York. p. 245. 